\title{
Representações do passado traumático em obras de Roberto Drummond e Bernardo Kucinski
}

Resumo:

A ditadura civil-militar brasileira foi revisitada por muitos romancistas contemporâneos, podendo a literatura sobre esse período ser considerada como uma forma de "arquivo da ditadura" (Figueiredo, 2017). Os escritores Roberto Drummond, em Hitler manda lembranças (1984), e Bernardo Kucinski, em K. Relato de uma busca (2011), colocam em cena personagens que, inseridas no período ditatorial, são atormentadas por lembranças da Segunda Guerra Mundial. Como em um quebra-cabeça inverossímil, a memória da perseguição aos judeus durante o nazismo ressurge estabelecendo conexões com o regime militar no Brasil. De cunho autoficcional ou sob a forma de pastiche, os dois romances propõem analogias singulares entre memórias não concorrenciais e possíveis cruzamentos traumáticos (Rothberg 2018). 0 caráter testemunhal das narrativas nos permite também estabelecer associações entre o passado exógeno do imigrante e a memória nacional. A ficcionalização do passado traumático parece contribuir para o estabelecimento de relações entre diferentes momentos históricos e a transmissão de uma memória intergeracional e afiliativa (Hirsch 2012).

Palavras-chave:

Roberto Drummond, Bernardo Kucinski, Shoá, ditadura militar, testemunha, traumatismo, memória nacional

Abstract:

The Brazilian civil-military dictatorship was revisited by many contemporary novelists, being the literature of that period considered as a form of "dictatorship file" (Figueiredo 2017). The writers Roberto Drummond, in Hitler manda lembranças (1984), and Bernardo Kucinski, in K.Relato de uma busca (2011), put on stage characters who, inserted in the dictatorial period, are tormented by memories of The Second World War. As in an untraceable puzzle, the memory of the Jews persecution during Nazism re-emerges by establishing connections with the military regime in Brazil. Self-fiction or pastiche-like, the two novels propose particular analogies between non-competitive memories and possible traumatic intersections (Rothberg 2018). The narratives' testimonial character also allows to establish relations between an exogenous past 
(the immigrant's) and the national memory. The traumatic past fictionalization seems to contribute to the building of relations between different historical moments and the transference of an intergenerational and affiliative memory (Hirsch 2012).

Keywords:

Roberto Drummond, Bernardo Kucinski, shoah, military dictatorship, witness, trauma, national memory

D'une part, au sens ethnologique et quasi religieux du terme, l'écriture joue le rôle d'un rite d'enterrement; elle exorcise la mort en l'introduisant dans le discours. D'autre part, elle a une fonction symbolisatrice; elle permet à une société de se situer en se donnant dans le langage un passé. (Michel de Certeau, apud Gagnebin 2018: 138)

Desde os meados do século XX, o Brasil acolheu imigrantes judeus de diferentes nacionalidades fugindo do antissemitismo na Europa e, a partir de 1945, sobreviventes da Shoá. Alguns escritores extraíram da memória familiar a matéria para a criação literária, outros se inspiraram em histórias alheias para imaginar a trama de suas narrativas sem estar diretamente vinculados a esse passado. Parte dessas narrativas literárias foi escrita pela segunda ou terceira geração de descendentes desses imigrantes. ${ }^{1}$

Não raramente, a ditadura militar brasileira (1964-1985) aparece como pano de fundo ou como cenário central de tais narrativas, ainda que de maneira alegórica ou dissimulada. Em alguns autores, esses dois períodos históricos dialogam evidenciando semelhanças ou sobreposições. É o caso de Hitler manda lembranças (1984), de Roberto Drummond, e, com quase trinta anos de intervalo, de K.Relato de uma busca (2011), de Bernardo Kucinski.

O enredo das duas obras está situado nos anos 1970 e meados da década de 1980, justapondo o presente das personagens exiladas no Brasil ao passado vivido na Europa: às vésperas, durante e após a Segunda Guerra Mundial. O estudo comparado desses dois romances objetiva sublinhar as aproximações possíveis entre períodos históricos díspares marcados pelo autoritarismo de Estado. Por razões diferentes, a figura da testemunha está colocada no centro das duas narrativas e permitir-nos-á refletir sobre a sua função para a construção de novas versões sobre a memória (trans)nacional e transgeracional perpassada pelo traumatismo e o sentimento de culpa. 


\section{Sobreposição de traumas: o passado do nazismo no presente da ditadura}

Ao pensar a Shoá como acontecimento histórico traumático e singular, matricial nesse sentido, Michael Rothberg (Rothberg 2018) propõe vê-lo como acontecimento desencadeador de um processo memorialístico a ser aposto a outros processos traumáticos, como, na análise feita pelo crítico, o genocídio da população negra e a guerra da Argélia (1952-1964). Forja o conceito de memória multidirecional e não concorrencial por meio da qual fatos sobrevindos de contextos históricos díspares podem ser colocados em diálogo em um processo de elucidação histórica em prol de um trabalho transnacional de memória. Como fenômeno do presente (Rothberg, 2018, p.14), a memória é feita de associações entre o passado lembrado e o presente vivido.

Nas duas narrativas aqui analisadas, o espaço e o tempo do rememorar é o Brasil ditatorial, no qual as personagens se situam, havendo justaposição do período ditatorial e da memória da

Shoá. Testemunhas diretas ou indiretas estiveram nos campos de concentração e extermínio ou lá perderam os seus familiares.

Hitler manda lembranças é um romance de estrutura fragmentária, pastiche de uma luta de boxe em seus diferentes rounds, que, por meio de digressões, nos conta a história de seis empregados da fictícia multinacional Brazil Corporation, em Belo Horizonte, 'os Seis Malditos', inscritos na lista dos 417 funcionários que, por razões econômicas, serão demitidos da empresa. De forma caleidoscópica, a história das personagens nos é contada pelo narrador protagonista Paulo Franz. Dentre estas personagens, dois tradutores e intérpretes da empresa: Adam Cohen, sobrevivente dos campos de concentração, e Stela Waitsman Mayer, órfã de pais judeus alemães e comunistas vítimas do nazismo.

Publicado no final do governo João Batista Figueiredo, o romance se situa em dois períodos diferentes: em 1973, na transição entre o governo Emílio Garrastazu Médici e o governo Ernesto Geisel, quando o narrador conhece Stela W. Mayer, e em 1984, às vésperas da redemocratização, ano em que são demitidos. Apesar de algumas alusões à repressão política e ao extermínio de militantes e grupos de esquerda tais como a Guerrilha do Araguaia, principalmente em meados da década de 1970, o período ditatorial é quase sempre relacionado à crise econômica dos anos Figueiredo. Assim, a alta taxa de desemprego dos anos 1980 é representada pela demissão iminente dos empregados da multinacional Brazil Corporation. No caos econômico no qual o Brasil está mergulhado em $1984,{ }^{2}$ alcançando uma inflação de $200 \%$ ao ano, as personagens representam a massa desempregada das grandes cidades brasileiras, exigindo, por meio de greves e passeatas, o fim da inflação, do desemprego e, em última instância, da própria ditadura.

Paralelamente à demissão iminente, Adam Cohen, terceiro da lista, vive obcecado pela ideia de que está sendo perseguido nas ruas de Belo Horizonte pelo ex-médico nazista Josef Mengele, de quem fora vítima durante o período que passou em Auschwitz. Sob a forma de flashs-backs por meio de subcapítulos intitulados "Recado de Auschwitz ", acompanhamos a personagem que vive de lembranças do passado, a nostalgia de um amor de infância assassinado e o pesadelo dos campos de concentração. Destes, traz a lembrança do fuzilamento do irmão Jacob e da morte da namorada Eva Zilberstein em câmera de gás, e a memória viva da série 
tatuada no braço: 184 467. Depois de ter sido acolhido como pupilo da França, acaba por migrar para o Brasil. Instalado em Belo Horizonte, investe tudo o que tem na perseguição do médico de quem fora cobaia. Arruina-se, perdendo a relojoaria e a loja de eletrodomésticos sem, no entanto, encontrá-lo, e passa a trabalhar como tradutor da multinacional Brazil Corporation.

Já Stela W. Mayer, cuja história nos é contada sob a forma de 'informes', é uma sobrevivente indireta da Shoá. Filha de Maria Waitsman Mayer e Karl Mayer, judeus alemães perseguidos pela Gestapo, foi criada por Frau Deutschland - alegoria cômica de uma Alemanha dilacerada -, alemã que perdera os próprios filhos na frente russa e que escondia a criança Stela e os seus pais em sua casa em Berlim. Estão prestes a deixar a Alemanha quando o pai é assassinado à queima-roupa pela Gestapo e a mãe é enviada a Ravensbrück, campo de concentração de mulheres. Anos mais tarde, depois da morte de Frau Deutschland, Stela W. Mayer muda-se para o Brasil, onde viviam três tios paternos, e passa a morar com a sua tia Miriam, dona de um renomado restaurante em Belo Horizonte. Tia Miriam tem alucinações com Hitler, vendo-o com frequência no próprio restaurante.

O romance Hitler manda lembranças foi raramente estudado e pouco conhecemos sobre a sua gênese. ${ }^{3}$ No entanto, as relações estreitas entre o nazismo na Europa e os dois períodos ditatoriais no Brasil do século XX dão à obra um caráter original, acentuado pelo caráter pós-moderno por meio do uso do pastiche de uma manifestação popular, o boxe, e do hibridismo de gênero, como diário, informes, biografia, enquete etc. (Outeiro Fernandes 2011: 230). Ao colocar em cena a história daqueles que foram exterminados ou sobreviveram à Shoá, o autor parece indicar relações transnacionais da catástrofe histórica.

De fato, às vésperas da redemocratização, Roberto Drummond dá vida ficcional a personagens reais: a homenagem prestada e uma das dedicatórias do romance nos leva a supor que, ao menos indiretamente, o autor se inspirou nas biografias de Olga Benário Prestes e Joseph Nichthauser para criar algumas de suas personagens: "Em homenagem a Olga Benário Prestes, que conheceu o inferno de Ravensbrück e foi assassinada pelos nazistas de Hitler", e "A Joseph Nichthauser, que sobreviveu a Auschwitz e a Buchenwald, e hoje nada mil metros toda manhã" (Drummond 1984: 5).

De fato, as personagens Maria Mayer, Stela Waitsman Mayer e Adam Cohen parecem ter sido calcadas, respectivamente, nas biografias de Benário e Nichthauser. Olga Benário Prestes foi entregue à Alemanha nazista pelo governo Getúlio Vargas pelo então chefe de polícia Filinto Müller, simpatizante do nazismo, e é a prova concreta da existência durante o Estado Novo de um terreno antissemita no Brasil que se concretizaria com o seu envio à Alemanha, seguido, anos mais tarde, de seu extermínio. Vários elementos aproximam a personagem Maria Mayer de Olga Benário, citada na obra como estando presa ao mesmo tempo que Maria Mayer em Ravensbrück (Drummond 1984: 35): judias alemãs, comunistas, separadas de suas filhas ainda pequenas e assassinadas no mesmo campo.

Como trataremos na segunda parte, há, na construção da personagem Adam Cohen, muitas semelhanças com o escritor e sobrevivente J.Nichthauser. ${ }^{4}$ Por ora, interessa-nos a personagem como alegoria do antissemitismo que grassou no Brasil na década de $1930^{5}$ e que, no 
romance, é transferido para o período ditatorial. Em um momento de crise econômica, Adam Cohen parece representar novamente uma espécie de bode expiatório da história.

De fato, às vésperas de sua demissão, ele está envolvido em um complô que tenta acusá-lo de um crime que não cometera - O crime da fita escarlate - , o de ter assassinado o ex-SS Fritz Doenitz. É claramente uma paródia do episódio antissemita e anticomunista conhecido como plano Cohen. ${ }^{6}$ Como o sobrenome de Adam Cohen indica, a paródia criada em torno da figura do imigrante judeu serviu para justificar a manutenção de Vargas no poder e o estabelecimento da ditadura do Estado Novo, com inclinação notoriamente antissemita.

Justapondo períodos históricos diferentes, a personagem é vítima, concomitantemente e de maneira metafórica, de três perseguições: sobrevivente da Shoá, vítima de retaliação econômica durante a ditadura militar e bode expiatório de um crime que, simbolicamente, remete ao antissemitismo durante a Era Vargas. De fato, se os dois primeiros são claramente explicitados, a acusação de ser comunista e de ter assassinado o ex-oficial SS é apenas sugerida de maneira irônica ao longo da narrativa: "O relato dos estranhos acontecimentos do último verão, envolvendo Adam Cohen como suspeito de um crime que ele não cometeu, começa numa sexta-feira quase inocente" (Drummond 1984: 11). Cohen será vítima de um antissemitismo não declarado, o que é corroborado pelo processo que se encarrega de transformar um inocente em culpado por um crime que não cometera, como sucedera com o plano Cohen, arquitetado pela Ação Integralista Brasileira (AIB) em apoio a Vargas. Nesse mesmo sentido, a imagem caricatural que lhe é atribuída de "médico-monstro-infantil" (Drummond 1984: 93) se assemelha à propaganda e aos estigmas antissemitas difundidos na Europa do pré-guerra, assim como no Brasil do Estado Novo:

Os que querem destruir Cohen reconstituíram sua vida, fizeram sua folha corrida desde os tempos da brincadeira de médico no sobrado do n. ${ }^{\circ} 43$ da Rua Nowolipki e dão uma conotação pecaminosa a uma ingênua brincadeira de crianças, comum em todo mundo. Apresentam Cohen como um pequeno monstro que dava injeção na perna de Eva e estão publicando uma série de reportagens, distribuídas por uma suspeita agência, com o título de «Relatório Cohen: As Várias Faces De Um Traidor», em diversos jornais do mundo. (ibidem)

As relações entre a Alemanha nazista e o Brasil se prolongam além do governo Vargas. Como indicado na obra, os dois sobreviventes do nazismo, Adam Cohen e tia Miriam, são atormentados pelas visões de Hitler e de Josef Mengele. Adam Cohen vê Josef Mengele, o seu carrasco em Auschwitz, nas ruas de Belo Horizonte e segue no seu encalço empregando todos os meios nessa perseguição obsessiva:

Era, tinha tudo para ser, Josef Mengele, o carrasco de Auschwitz. Cohen estava armado com um revólver 38 e era dono de uma relojoaria e, naquela hora, desceu correndo a escada do n. ${ }^{\circ} 366$ da Rua Caetés, disposto a agarrar Mengele. Mas Josef Mengele desapareceu entre as filas dos ônibus e lotações, no febril anoitecer da Rua Caetés, na hora do rush. De lá para cá, Cohen se dedicou a 
uma caça solitária e sem êxito de Josef Mengele, que era visto numa fazenda de Mato Grosso, como criador de gado, depois aparecia olhando vitrina numa rua de Curitiba ou deslocava-se para a fronteira com o Paraguai, onde por certo vivia. Como consequência de sua caça a Mengele, Cohen faliu e perdeu a relojoaria, depois ficou sem a loja de eletrodomésticos. (Drummond 1984: 17)

Visões que não são completamente alucinatórias, já que países como o Uruguai, a Argentina, o Paraguai e o Brasil tornaram-se a terra de exílio de muitos ex-SS em fuga dos tribunais internacionais.

De fato, Mengele circulou entre 1960 e 1979 pelo solo brasileiro sob identidade falsa. $\mathrm{Pu}-$ blicado em 1984, Hitler manda lembranças parece ser visionário daquilo que, em 1985, ano da redemocratização, será um fato: a descoberta da ossada do nazista mais procurado, que teria vivido durante vinte anos no Brasil, e cuja identidade seria confirmada em 1992 após exame de DNA.7 O passado traumático da personagem é reavivado por fantasmas não tão fantasmagóricos assim. Adam Cohen, cobaia de Mengele, e Stela Waitsman Mayer, cuja mãe foi também cobaia do médico Karl Gebhardt, caminham ao lado de carrascos nazistas.

Na esteira da reflexão sobre cruzamentos traumáticos e uma memória não concorrencial, um diálogo interessante poderia ser tecido sobre o que, em princípio, denota ser apenas coincidência histórica. $\mathrm{O}$ que tais fatos teriam a revelar sobre a sociedade que abrigou nazistas e anistiou, concomitantemente, torturadores? Assim, o medo da perseguição e de suas consequências vivido pela personagem no campo de concentração ecoa no presente diegético dos crimes cometidos pela ditadura. A ficção permite-lhe esclarecer períodos recalcados da história nacional: a terra de asilo para os judeus sobreviventes também o foi para os seus carrascos. Ao revisitar a biografia de Olga Benário Prestes no final da ditadura militar, há, sem dúvida, a intenção implícita de dar a ver a cumplicidade do governo brasileiro, o de Getúlio Vargas, com o governo nazista, aguilhoando a memória coletiva sobre as possíveis relações entre regimes autoritários na América Latina e outras nações. Logo, o autor nos exorta a perceber relações possíveis entre o presente e o passado, entre políticas de repressão transnacionais. Cumplicidade que iria se repetir em parcerias entre governos ditatoriais na América Latina, nos Estados Unidos e na Europa no pós-guerra, dentre as quais parcerias militares no exercício da repressão, ${ }^{8}$ e a abertura do país às multinacionais americanas, representadas no romance pela Brazil Corporation.

A reconstituição de um acontecimento histórico por um dos principais representantes da literatura pop no Brasil (Vieira 1986: 428-429) dá respaldo literário a questões traumáticas que saem do negacionismo para penetrar prateleiras de livrarias, dando vida e protagonismo a personagens marginalizadas da história de um Brasil pós-ditatorial. O romance se inscreve no que Marianne Hirsch classificou como memória afiliativa ou transgeracional, ou seja, a herança de um trauma histórico por uma geração indiretamente ligada ao mesmo passado e com o qual estabelece uma relação empática (Hirsch 2012: 140).

Roberto Drummond rememora a tragédia da Shoá e de seus sobreviventes apesar de não ter nenhuma ligação com a mesma. Confundido pelas contradições do seu presente, ou seja, a 
transição por anistia entre a ditadura e a fase de redemocratização, o leitor é levado a vasculhar o passado coletivo e não somente o mais recente. Como num jogo de bonecas russas, a violência escamoteada do passado recente se repercute em um passado anterior, também recalcado, e as histórias individuais transformam-se em importantes instrumentos para "uma confrontação ética com um passado que ainda não foi trabalhado" (Rothberg 2018: 349) (tradução livre).

K. Relato de uma busca (2011), de Bernardo Kucinski, também realiza um trabalho de memória ligado a um acontecimento traumático. Narra a história de um pai, de nome $\mathrm{K}$, que durante todo o romance busca pelo paradeiro de sua filha. O romance é uma autoficção inspirada na história da família de Bernardo Kucinski, cuja irmã Ana Rosa Kucinski Silva, militante da Aliança Libertadora Nacional (ALN), desapareceu em abril de $1974 .{ }^{9}$ À procura por aquela que rapidamente se compreenderá assassinada, ainda que os seus restos mortais nunca tenham sido encontrados, $\mathrm{K}$, e o relato de sua busca, uma enquete histórica e ficcional, se adentra nos meandros da ditadura militar brasileira.

Ao longo dos capítulos, o período ditatorial em que K vê a filha desaparecer é mostrado sob a ótica de diferentes atores, numa versão polifônica pela qual o autor procura dar voz aos envolvidos na morte de Ana Rosa Kucinski Silva, que, como muitos outras, foi calada pela lei da anistia. Depois de seu desaparecimento, a professora do Instituto de Química da Universidade de São Paulo será exonerada do cargo de docente por não comparecimento ao trabalho. Fato real e contestado pela família, ${ }^{10}$ ele é emblemático do silêncio que se criou em torno dos desaparecidos políticos.

A narrativa mostra o itinerário árduo de um pai que ousa bravar um sistema que, por todos os meios, tenta dissuadi-lo de buscar pela filha. O caminho tortuoso o coloca em contato com parte da vida desconhecida da filha e de seu militantismo e o permite compreender a cortina de ferro que se criou na sociedade brasileira sobre os crimes cometidos pelos militares. A verdade sobre o seu desaparecimento só será revelada ao pai anos depois de iniciada a sua busca, não pelo Estado brasileiro, mas por presos políticos que K visitou no presídio do Barro Branco; dentre eles, alguns membros também da ALN. Apesar da presença implícita do irmão escritor, da qual falaremos mais adiante, a narrativa está, em grande parte, centrada na busca desse pai e é reveladora de uma sensação de repetição que, como no romance de Roberto Drummond, nos permite detectar as justaposições históricas reveladas pelo romance.

De fato, ao longo da narrativa, e sob a forma de associações e flashs-backs, a procura pela filha faz ressurgir, paulatinamente, lembranças do passado de K. Inspirada na biografia de Majer Kucinski, pai do escritor, a história de K é a de um imigrante judeu polonês que chega ao Brasil em $1935 .{ }^{11} \mathrm{O}$ poeta e idischista $\mathrm{K}$ foi perseguido pela polícia política polonesa devido a seu engajamento político no partido sionista de esquerda do qual foi um dos fundadores e só é liberado da prisão sob a condição de imigrar para o Brasil. ${ }^{12}$

Já na primeira noite em que espera pela filha, K tem um sonho com a própria infância na Polônia czarista. Como uma premonição, o sonho parece anunciar algo trágico: 
Naquela noite sonhou ele menino, os cossacos invadindo a sapataria do pai para que lhes costurasse as polainas das botinas. Despertou cedo, sobressaltado. Os cossacos, lembrou-se, haviam chegado justo no Tisha Beav, o dia de todas as desgraças do povo judeu, o dia da destruição do primeiro templo e do segundo, e também o da expulsão da Espanha. (Kucinski 2016a: 17)

De fato, o evento trágico anunciado pelo sonho seria descoberto ao fim de uma longa procura. Impulsionado pela lembrança de infância que o sonho o faz reviver, segue em busca de sua filha e penetra em um sistema cuja organização labiríntica servia para apagar pistas, dissuadir os familiares.

A única filha é a predileta do pai - "Main teier techterl, minha filhinha querida", como sempre repete. A cada passo em busca da filha desaparecida, o próprio passado vai emergindo involuntariamente, como se o presente fosse, de certa forma, uma repetição. Assim, cada passo o faz recordar a vida pregressa: "Não quis se abrir com o delegado, apenas insinuou. Por isso também não lhe deu o endereço da Padre Chico, deu o seu como sendo o dela e o da loja como se fosse o seu. Sem perceber, K. retomava hábitos adormecidos da juventude conspiratória na Polônia" (Kucinski 2016a: 20),

O pai compara o que observa na polícia política no Brasil à sua experiência de prisioneiro político. O que descobre sobre os meandros da ditadura brasileira e de sua forma de repressão o faz imediatamente pensar em seus últimos anos na Polônia, como se dois tempos, lugares e contextos históricos e políticos tão diferentes pudessem ser aproximados. Ao contrário da prática de desaparecimento de corpos, a polícia polonesa registrava os seus presos e avisava aos familiares. A reflexão é levada a seu extremo, quando o método de desaparecimento dos corpos é comparado ao extermínio em campos de concentração durante a Shoá:13

Variavam cenários, detalhes, circunstâncias, mas todos os vinte e dois casos computados naquela reunião tinham uma característica comum assombrosa: as pessoas desapareciam sem deixar vestígios. Era como se volatilizassem. O mesmo com os jovens do Araguaia, embora estes já se soubesse estarem mortos. A freira anotava caso por caso. Também recolhia as fotos trazidas pelos familiares.

K. tudo ouvia, espantado. Até os nazistas que reduziam suas vítimas a cinzas registravam os mortos. Cada um tinha um número, tatuado no braço. A cada morte, davam baixa num livro. É verdade que nos primeiros dias da invasão houve chacinas e depois também. Enfileiravam todos os judeus de uma aldeia ao lado de uma vala, fuzilavam, jogavam cal em cima, depois terra e pronto. Mas os goim de cada lugar sabiam que os seus judeus estavam enterrados naquele buraco, sabiam quantos eram e quem era cada um. Não havia a agonia da incerteza; eram execuções em massa, não era um sumidouro de pessoas. (Kucinski 2016a: 24-25)

Alertado pelos conterrâneos sobre os espiões de Getúlio Vargas e, logo, sobre o perigo de se manter qualquer atividade política no Brasil, não podia suspeitar que o mesmo se repetisse ali, em seu bairro, com a presença de delatores dentre os comerciantes e filhos de judeus: "É 
verdade que quando chegou ao Brasil em 1935, fugido da polícia polaca, os patrícios o alertaram contra os espias de Getúlio, zei zainen umetum, eles estão em toda a parte, advertiram em iídiche. Mas isso foi na época do fascismo. E eis os espias de novo em toda a parte. Ou sempre estiveram?" (Kucinski 2016a: 32)

Sua busca parece interminável, tornando-se o centro do seu quotidiano, pois não mede esforços para ter informações sobre a filha, que, aos poucos, considera morta. Tentam confundi-lo, dando-lhe informações contraditórias: ora estaria presa, ora nunca esteve presa, ora achou exílio em Portugal. Enganado pelos próprios informantes, ele se vê envolvido em um emaranhado de mentiras e se dá conta de que estava diante de algo bem diferente de tudo o que havia experimentado na Polônia, tratava-se de um sistema de repressão impenetrável. $\mathrm{O}$ pai não desiste e consegue ser recebido por um general. Ao subir os degraus do Clube Militar, é levado imediatamente a lembrar de outras escadarias, também em mármore, que subira na delegacia na Polônia em busca da irmã desaparecida:

Naquela noite, no Clube Militar, à medida que subia os degraus de mármore branco talhados em forma de pétalas, que conduziam ao andar superior, K. observava a imponência da construção, com suas linhas neoclássicas. Lembrou-se subitamente de outra escadaria em outros tempos, em Varsóvia, igualmente em mármore e também no estilo neoclássico, que ele galgara aos saltos, ainda jovem e valente, para indagar o paradeiro de sua irmã Guita, presa num comício do partido que ajudara a fundar, o Linke Poalei Tzion. Alarmou-o a emergência da lembrança, que julgava soterrada sob os escombros da memória. (Kucinski 2016a: 36-37)

A associação que surge de maneira inconsciente, aparentemente provocada por um estímulo visual de um déjà vu, as escadarias em mármore, parece anunciar a repetição do trágico: o destino da filha e a sua semelhança com o da própria irmã. K está frente à mesma história cujo fim conhece de antemão. A irmã mais velha e a única filha, militantes engajadas e desaparecidas nos porões de dois sistemas repressivos. O espectador impotente da cena, $\mathrm{K}$, irmão e pai, opositor engajado em sua mocidade, se vê frente a mais um impostor e à semelhança de métodos de repressão. O cenário, como num teatro, rebobina a cena a ser representada. As personagens, tia e sobrinha, representando o mesmo papel. Por trás da falácia - fugiram com um amante -, a verdade nunca assumida pelos órgãos de repressão:

Foi solto na condição de emigrar, além da propina coletada pelos amigos de militância. Sua irmã, Guita, cinco anos mais velha, não tivera a mesma sorte. Morreu tuberculosa no frio da prisão. A imagem repentina de Guita puxou a do delegado que o expulsara do topo da escadaria de Varsóvia aos gritos de que sua irmã nunca fora presa, de que teria fugido para Berlim, isso sim, com algum amante. Ainda pensava em Guita quando chegou ao general, que o recebeu de maus modos. Mandou-o sentar com rispidez. Reclamou que ele estava espalhando na comunidade judaica acusações pesadas e sem fundamento contra os militares. E se sua filha fugiu com algum amante para Buenos Aires? O senhor já pensou nisso? (Kucinski 2016a: 37) 
A repetição se dará também em mais uma cena, quando, extenuado pela busca que se estendeu ao longo de quatorze meses, $\mathrm{K}$ vai ao encontro de presos políticos no presídio do Barro Branco: "K. conhece o quartel há mais de cinquenta anos. Nunca imaginou que um dia ali entraria carregando pacotes de cigarros para presos políticos (...) Quase diariamente K. percorria com sua charrete de mascate a estrada de terra que atingia a invernada pelo lado oposto ao da guarnição" (Kucinski 2016a: 157). De fato, a busca pela filha também o leva a um outro capítulo da sua história: a de um imigrante judeu polonês recém-chegado ao Brasil. Naquele momento, o presídio era apenas um quartel, imagem familiar de um imigrante mascate que, cinquenta anos mais tarde, ali entraria para confirmar a morte da própria filha:

Os presos já o esperavam; todos homens e a maioria jovens. Estavam bem vestidos, barbeados. Mas K. adivinhou pela dureza dos semblantes que estavam encarcerados havia muito tempo. Conhecia esse olhar, que não se confunde com nenhum outro. Era o seu olhar de cinquenta anos atrás (...) Alguns conheceram sua filha e o marido, eram da mesma organização clandestina; todos conheciam a história, inclusive quem os havia delatado. Sabiam que já estava morta havia muito tempo. (Kucinski 2016a: 160-161)

O presente desata o nó de lembranças que não obedece a uma cronologia certa, mas a uma memória involuntária. De fato, a memória é, notadamente, o que esquecemos e que ressurge sob forma de vestígios (apud Gori 2003: 101). Assim, das interconexões inconscientes entre os diferentes momentos passados e o presente surgem as lembranças do pai. A caminho da ala dos presos políticos no quartel do Barro Branco, lembra-se da sua própria prisão e de como fora humilhado. Sente-se arrastado em direção a um espaço temido na Polônia e desde que chegou ao Brasil: "A cada passo em direção a essa ala, K. retrocedia na memória aos tempos de sua própria prisão na Polônia. Lembrou-se novamente de quando o arrastaram acorrentado pelas ruas de Wloclawek para humilhá-lo perante os comerciantes. Agora também se arrastava, alquebrado, embora sem correntes" (Kucinski 2016a: 159).

No calor do presídio em São Paulo, lembra-se das comidas levadas com sacrifício pela mãe à prisão durante a primavera quente na Polônia. Abraçado, por sua vez, aos mantimentos que ele levava aos prisioneiros do Barro Branco, tem consciência, por experiência, do quanto cigarros e barras de chocolate são gêneros importantes para presos.

K. agarra com força a sacola com as caixas de cigarros e as barras de chocolate. Estão se aproximando da ala semi isolada dos presos políticos. O sol o incomoda. Transpira profusamente pela testa, pelo rosto todo. Tira do bolso um lenço com a mão esquerda e enxuga-se. Então se lembra da primavera quente polonesa em que a mãe lhe foi levar na prisão as comidas do Pessach. Eram dez irmãos, vivendo no limite da miséria, mas a mãe, infatigável, nunca deixou de lhe levar nos dias de visita um pão ou um ovo cozido e nos dias de festa uma comida especial. Naquela prisão polonesa ele descobriu a importância dos cigarros e barras de chocolate. Era o que ele trazia agora, aos presos do Barro Branco. [...] (Kucinski 2016a: 159-160) 
Nessa visita, é-lhe revelado, de modo oficioso, aquilo que para ele já era uma certeza: a filha havia sido assassinada há muito tempo pelos agentes do governo. Na prisão do Barro Branco, que cinquenta anos atrás ladeava de carroça para o trabalho de mascate, confirma o que os militares não assumiram publicamente.

Como em Roberto Drummond, mas de maneira invertida, Kucinski faz coabitar dois momentos históricos. Por um processo de associações involuntárias, K é levado a lembrar-se do período de perseguição e repressão sofridas na Polônia, do extermínio de grande parte de sua família durante a guerra, estabelecendo paralelos entre a sua história e a história do desaparecimento da filha e a busca pelo seu corpo. Se em Drummond a ditadura é um pano de fundo para a memória do passado dos sobreviventes, em Kucinski a escrita aparece como 'bloco mágico' sobre o qual o passado do imigrante judeu e de sua família vai ressurgindo à medida em que os fatos do presente - a filha desaparecida pelo sistema de repressão no Brasil - vão sendo revelados, justapondo as duas temporalidades.

A ficcionalização do real reflete o quanto o mesmo é irrepresentável. Assim, após ter a certeza da morte da filha, $\mathrm{K}$, escritor em iídiche de histórias do país de imigração, planeja escrever o que vivera. No entanto, o iídiche, língua de afeto e de cultura de dez milhões de judeus, praticamente exterminada juntamente com os seus falantes (Minczeles 2005), parece não se adequar à missão do pai-escritor:

Além disso, ponderava K., se o iídiche era uma língua de diminutivos carinhosos, uma língua doméstica de artesãos e gente muito pobre, de carroceiros e camelôs, mais motivo ainda para poder expressar seus sentimentos em iídiche [...] Mas ele não conseguia. Será por ser o seu iídiche casto demais para expressar a obscenidade do que lhe acontecera? [...] Aos poucos K. foi se dando conta de que havia um impedimento maior. Claro, as palavras sempre limitavam o que se queria dizer, mas não era esse o problema principal; seu bloqueio era moral, não era linguístico: estava errado fazer da tragédia de sua filha objeto de criação literária, nada podia estar mais errado. (Kucinski 2016a: 127-128)

Assim, só o irmão-autor saberá, um ano depois da publicação do livro, qual destino teve a irmã. Nesse sentido, a visão do autor vai além do que o pai pôde conhecer sobre a história da filha. A morte transformada em suicídio na fição, transferindo para outras personagens o assassinato sob tortura, será revelada um ano depois, em 2012, pelo ex-delegado do DOPS/ ES, Cláudio Guerra, em depoimento a dois jornalistas (Guerra et alii 2012) e confirmada pelo relatório da Comissão Nacional da Verdade em 2014.

Também o irmão-escritor, diante da impunidade por um crime assumido diante de um largo público televisivo, só poderá transcrever aquilo que lhe era impossível contar: "Não me senti capaz de escrever com as minhas próprias mãos o que ouvi. Recorri a uma transcrição da entrevista que aí está na íntegra"(Kucinski 2016b: 77). O excerto que relata o fim dado pelos militares aos restos mortais de Ana Rosa Kucinski Silva e Wilson Silva será transcrito por Bernardo Kucinski em seu díptico Os Visitantes (2016), no capítulo 'Post-mortem'. Na entrevista 
transcrita, descobrimos que o corpo brutalmente violentado e torturado da irmã foi incinerado na caldeira da usina de cana-de-açúcar da fazenda Cambahyba em Campos dos Goytacazes, construída em 1974, ano do desaparecimento de Ana Rosa Kucinski, e, a que tudo indica, construída para efetuar a incineração dos corpos de militantes para queima de arquivo:

Eu e minha ex ficamos em silêncio. Nossas mãos haviam se encontrado no instante em que o agente falara do forno, e permaneciam unidas...O jovem procurador disse que é truque, que é mentira, que não aconteceu, que os corpos não foram incinerados num forno de assar melaço. Eu e minha ex sabíamos que era verdade. Sempre soubemos. (Kucinski 2016b: 83)

Cena tão próxima àquelas perpetradas nos campos de concentração, como inúmeros sobreviventes o testemunharam, e que, no caso da família Kucinski, se apresenta como repetição de um "evento-limite" singular (Seligmann-Silva 2000: 77). A comparação entre os campos de extermínio e as atrocidades ocorridas durante a ditadura militar brasileira seria, por certo, precipitada e possivelmente redutora. No entanto, os traumas passados são reavivados no presente daqueles que, testemunhas auriculares ou herdeiros da memória dos ascendentes (ou "testemunho do testemunho" apud Ribeiro 2013: 30), veem o presente, ainda que em contexto histórico e político diverso, como repetição da catástrofe. Inscrito no exercício de uma memória transnacional e não concorrencial, o trauma é uma constante nesses relatos e aparece como repetição, "memória de um passado que não passa" (Seligman-Silva 2008: 69). Como veremos, está indissociavelmente ligado à figura do sobrevivente ou de seus descendentes e implica a herança de um sofrimento e de um sentimento de culpa.

\section{Representação e transmissão do traumatismo}

Inspiradas em histórias de imigrantes ou exilados no Brasil, as duas narrativas trazem à tona representações do passado traumático e de seus vestígios no presente. Bernardo $\mathrm{Ku}-$ cinski, na história de seus pais, imigrantes judeus poloneses; Roberto Drummond, como já foi dito, na biografia de Olga Benário Prestes, judia alemã, e nas memórias de Joseph Nichthauser, sobrevivente da Shoá, que são pontualmente colocados em cena no romance. Neles, somos confrontados com a figura da testemunha ocular, a mais direta, e a auricular. Interessa-nos, nessa segunda parte, refletir sobre o lugar ocupado pela testemunha em seus diferentes níveis. Nesse sentido, serão discutidas as reverberações do passado no presente das personagens por meio do evento traumático e do sentimento de culpa e de responsabilidade herdados.

Assim que sobreviventes se tornaram narradores de suas experiências traumáticas nos campos de concentração, o testemunho tornou-se uma peça central para o trabalho de memória (Seligmann-Silva 2000: 87). Recusando toda a hierarquização entre diferentes catástrofes históricas, Rothberg chama-nos a atenção, no entanto, para o caráter matricial da Shoá no tocante à reflexão sobre a memória e o papel do testemunho. De fato, como nos lembra o autor, a Shoá está na origem de teorias e reflexões sobre o papel da memória que podem servir como paradigma operacional para pensar outras catástrofes históricas. Segundo Seligmann-Silva, 
se "o testemunho se tornou uma modalidade crucial da nossa relação com os acontecimentos de nosso tempo - com o trauma da história contemporânea", é porque ele passa a ser a possibilidade de libertação da cena traumática através de um mergulho na linguagem e na tentativa de representação.

A testemunha traz à tona a experiência traumática, remetendo a um transbordamento de sentido e à incapacidade de representação daquilo que é, de fato, irrepresentável, realidade radical do campo de concentração (Semprun 1994: 256). No entanto, a escrita, sobretudo a literária, acena com uma promessa de narrativização (Coquio 2015: pos.5091), que, se não traduz o passado inenarrável, possibilita uma forma de aproximação do mesmo, para uns catártica, para outros inscrita em um trabalho memorial. Nesse sentido, a linguagem pode ser, nos termos de Seligmann-Silva, o invólucro ao indizível da experiência limite, ao mesmo tempo em que, para Rothberg, fornece "sepultura às histórias traumáticas" (Rothberg 2018: 342).

Nem sempre a reelaboração ou representação do passado traumático pela escrita é realizada pela testemunha direta - como em Primo Lévi, Charlotte Delbo ou Joseph Nichthauser. Muitas vezes, como afirma Jorge Semprun, continuar a viver é incompatível com a escrita do trauma pois, e Charlotte Delbo complementa, é preciso desaprender para voltar à vida. ${ }^{14} \mathrm{O}$ silêncio do sobrevivente, como vimos em Kucinski, pode ser um modo de proteger os próprios filhos, já que o drama de seus pais, imigrantes fugindo de perseguição política e do antissemitismo na Europa, lhes será por muito tempo ocultado. Para protegê-los, ou por se sentirem vergonhados ou culpados, o passado dos pais é escamoteado dos filhos. No entanto, o seu silêncio protetor é eloquente e acaba por arraigar raízes na vida das gerações seguintes, um trauma que pode, inclusive, se manifestar psicossomaticamente. ${ }^{15}$

Adam Cohen e Stela W. Mayer provavelmente não se conhecem, mas trabalham como intérpretes na mesma empresa. Nos dois casos, o retorno do trauma se inscreve numa presentificação do passado que, como veremos, se imiscui ao sentimento de culpa e a um dever de memória.

Adam Cohen tem a missão de contar, tornar-se o superstes (Agamben 2003: 17), i.e., a testemunha parcial, ${ }^{16}$ e narrar o "inassumível" como razão para sobreviver. Sob a forma de um diário dentro do livro, Adam Cohen escreve as memórias do campo de concentração transmitindo, pela escrita, o testemunho daqueles que lhe pediram para ser o mensageiro de seu infortúnio. Em "Recado de Auschwitz", Cohen torna-se tanto a testemunha ocular como também auricular dos recados enviados pelos prisioneiros encontrados. Ele vai sobreviver, é a certeza que têm aqueles que vêm testemunhar. É jovem, tem mais resistência e se vê incumbido de um dever de memória, o de transmitir um recado ao mundo, de que Auschwitz foi possível: "-Ei, você é Cohen? - Sim, sou. - É você que está aceitando recados para transmitir ao mundo quando esse pesadelo de Auschwitz acabar? - Sou eu"(Drummond 1984: 88). Em sua maioria, os recados dados por aqueles que não sobreviveram, e que o escolhem pela certeza de que ele iria sobreviver para contar, expressam a não aceitação da desumanização imposta pelo sistema de extermínio, ainda que a tortura e a morte pareçam inevitáveis. 
Três recados a serem transmitidos. O de Bernardo Schorr à esposa Bertha Schorr: que seja alegre, que continue dançando e usando o vestido verde de que tanto gostava (Drummond 1984: 88-89). O de Leopold Fischer, que perdeu toda a sua família e mulher amada nos campos e cujo recado é menos um testemunho que a expressão de um desejo: pede a Adam Cohen que se embriague em Viena e urine em uma árvore à qual deve transmitir um recado. Sem família, o seu testemunho é menos uma mensagem a ser transmitida que um desejo de liberdade expresso na ação, a de sair para beber às sextas-feiras com os amigos e, com satisfação, urinar em uma árvore: "Lembra como era bom urinar em liberdade? "(Drummond 1984: 139-140). Lembra-se também do maiô verde se sua amada Esther, morta na câmera de gás, e a lembrança é um acalanto para a falta de sentido no presente do campo. Por sua vez, a personagem Nathan Waismann, ciente de que vai morrer, pede a Adam Cohen que diga ao mundo ao que o médico Josef Mengele o submeteu em Auschwitz, 'no inferno dentro do inferno': o médico nazista o castrou. Nesse caso, não há expressão de lembranças alegres, apenas denúncia da tortura de que foi vítima.

O "Recado de Auschwitz" é a alegoria de uma humanidade perdida, de uma humanidade e prazer de viver que o campo e o nazismo lhes roubaram, imersos num ambiente de morte. Assim, o que lhe pedem para transmitir é menos o horror dos campos do que o resto de humanidade que lhes resta na memória e no desejo de uma outra vida possível. De fato, o que Adam Cohen traz na memória é tão somente uma visão do evento-limite que somente aqueles que viveram poderiam testemunhar (Agamben 2003: 36).

Ao longo da obra, as lembranças de Adam Cohen dos campos de concentração são intercaladas por digressões que tanto o transportam a um passado anterior aos campos quanto o trazem de volta ao presente da narração. A sua sobrevida parece depender da sua capacidade de evasão, de suas próprias lembranças, que, intercaladas às lembranças alheias, o fazem regressar à infância e à adolescência. "Recordações do paraíso" é o subtítulo dado às digressões da personagem em direção a Varsóvia, ao seu gueto e às recordações de sua relação com Eva Zilberstein, amiga de infância e namorada, presa em Auschwitz. Intercalam-se, assim, "Recados de Auschwitz" e "Recordações do paraíso" na reconstituição da vida da personagem antes de sua chegada ao Brasil. Submetido a diferentes formas de sofrimento e de tortura, inclusive às experiências orquestradas por Mengele, resgata um passado anterior em que, inconsciente do mal por vir, vive a descoberta do amor e da sexualidade com a vizinha Eva Zilberstein:

Agora, parado na Esquina dos Aflitos, com o pensamento diante do sobrado ${ }^{\circ} 43$ da Rua Nowolipki, Cohen sente na palma da mão que segura a maçã, o arrepio na perna de Eva e imagina que a brincadeira de médico vai começar outra vez, pois nem Hitler, nem a Gestapo, nem os Guardas SS de Auschwitz e Buchenwald, nem o médico e monstro Josef Mengele conseguiram proibir aquele arrepio da perna de Eva na palma de sua mão. E foi o corpo nu de Eva Zilberstein, quando ela era uma moça, que o ajudou a continuar vivo em Auschwitz e Buchenwald (Drummond 1984: 93) 
Em seu diário, Adam Cohen reconstitui a sua relação com Eva Zilberstein ao longo da infância e adolescência, uma história de amor em meio ao lento aniquilamento do gueto de Varsóvia. A capacidade de amar e a descoberta da sexualidade é a humanidade que lhes restava no gueto e que nem o nazismo poderia lhes roubar. O amor por Eva, gaseificada em Auschwitz, torna-se oração à vida e capacidade de resistir às experiências levadas a cabo por Mengele, como expressa a oração proferida em nome de Eva em meio à tortura sofrida ("Ave Eva, cheia de graça/a esperança do mundo, esteja contigo/ no arrepio da tua pele - faz com que eu viva [ ]", Drummond 1984: 96). Consciente do evento trágico - o extermínio da irmã e da amada no campo de concentração -, Adam Cohen sobrevive graças às lembranças de Eva, lembranças ainda capazes de torná-lo humano em meio ao processo irreversível de desumanização.

Há em sua memória sobreposição do tempo trágico e de um tempo anterior, de seu amor adolescente por Eva Zilberstein, como uma fonte de vida de que não é possível esquecer, apesar do horror dos campos que viria dissolver passado e futuro num presente eterno. Do mesmo modo, Charlotte Delbo, em sua trilogia sobre a experiência concentracionária no campo de concentração, evoca as lembranças da vida anterior a Auschwitz que, com a chegada da primavera, lhe advinham. No campo, a chegada da primavera em meio à destruição e tortura do humano parece perder todo o sentido. De imediato, é levada a um passado que em nada se parece com o presente, a não ser o que ficou guardado na memória e que, involuntariamenete, é despertado pela mudança da estação. ${ }^{17}$

O diário de Adam Cohen funcionaria, assim, como resistência ao processo de reificação. Para o mensageiro de Auschwitz, a escrita de seu testemunho e do testemunho da testemunha cohabita com as lembranças indeléveis da vida antes do evento-limite. As lembranças de Eva transportam Cohen para um tempo anterior à catástrofe, como um antídoto ao esvaziamento de sentido da vida pós-traumatismo.

Às recordações do convívio com Eva no gueto de Varsóvia e o horror nos campos de concentração, o presente vem imiscuir-se como arremate. Assim, a sobreposição temporal utilizada para representar a vida psíquica e o quotidiano de Adam Cohen acaba por intensificar a experiência de reificação de que foi(foram) vítima(s) e as reverberações possíveis dessa história do outro lado do atlântico, onde ex-SS cohabitam com sobreviventes, e judeus foram bodes expiatórios de regimes ditatoriais.

Stela W. Mayer também vive entre dois tempos: o passado vivido na Alemanha em companhia de Frau Deutschland, quer fugindo da Gestapo quer vivendo em uma Berlim bombardeada, e as lembranças mais difusas que lhe ficaram dos pais: uma carta-testamento e uma pequena escultura esculpida com o barro do campo de concentração, enviadas pela mãe de Ravensbrück antes de morrer como cobaia do médico nazista Karl Gebhardt, que lhe injetava o virus da malária. Stela também sente o perfume da mãe pelas ruas de Berlim, memória olfativa que também encontramos em Adam Cohen quando associa a lembrança de Eva Zilberstein ao cheiro da maçã que a avó dela vendia fora do gueto de Varsóvia.

Na carta, como nos testemunhos dados a Adam Cohen, a mensagem que a mãe transmite à filha é um apelo à vida, ao direito de continuar a ser feliz, apesar de os campos de extermínio 
terem existido. Em um outro momento, Stela e o narrador, Paulo Franz, consomem LSD e, em sua viagem alucinatória, Stela encontra-se com a mãe em Ravensbrück. Ali, já adulta, a filha "ouve" - ou deixa emergir do seu inconsciente - o relato que a mãe lhe faz de seu quotidiano de sofrimento e também de seu desejo de reviver os gestos banais de uma vida em liberdade, como o de tomar sorvete de morango. Na carta deixada à filha, a mãe faz um apelo à vida e à memória dos pais: apesar de Ravensbrück, a filha deve ser feliz e niguém pode roubar-lhe esse direito, e deve se orgulhar dos pais, judeus e comunistas. Já no encontro proporcionado pelo uso de LSD, a mãe lhe relata o pesadelo de sobreviver em Ravensbrück e o sonho com a liberdade. Ao contrário da carta otimista escrita por uma mãe à filha que nunca mais reverá, a alucinação experimentada por Stela faz emergir suas próprias representações e vai rememorar o conhecimento sobre os campos de concentração, a partir do que ouvira ou lera, informações para imaginar a fala da mãe, escrevendo postumamente o testemunho que a mãe não dera.

Testemunhas do passado traumático, Adam Cohen e Stela Waitsman Mayer vivem um presente em suspensão. Sentem-se culpados por estarem vivos, ao contrário dos familiares e companheiros de prisão, ou por ainda se sentirem felizes. De fato, vergonha e culpa por terem sobrevivido, mal do sobrevivente (Agamben 2003: 95-96), os acompanham diariamente. Adam Cohen sobrevive várias vezes às mortes anunciadas nos campos de concentração: à marcha dos dez mil prisioneiros de Auschwitz a Buchenwald; ao fuzilamento de prisioneiros judeus em Buchenwald, no qual perde o irmão Jacob pouco antes da chegada do exército russo. A resposta de cumplicidade com os que morreram - toda a família, a mulher amada e os companheiros de prisão - externaliza-se em culpa e autopunição:

É verdade que Cohen sentia, às vezes, um quase incurável sentimento de culpa por estar vivo, quando toda família e a única mulher que ele realmente amou estavam mortos. É também certo que Cohen, em determinada fase, andava com uma agulha na parte de dentro da gola do paletó e, quando estava alegre, furava o dedo da mão esquerda até brotar uma flor de sangue. Era, no entanto, mais do que uma penitência pelo pecado de estar vivo, uma homenagem a seus mortos. (Drummond 1984: 16)

Em Cohen, o sentimento de culpa acarreta um sentimento de injustiça - suspeita de que o médico que o torturou com suas experiências viva livre no Brasil - , desejo de vingança - a vã perseguição de Josef Mengele no Brasil que acaba por arruiná-lo economicamente - e empatia pelos marginalizados da sociedade - aliás, a "Esquina dos Aflitos", em Belo Horizonte, é um de seus locais prediletos pois pode observar os desvalidos da sociedade belo-horizontina com os quais se identifica. Por isso, a tentativa de transformá-lo em responsável de um crime que não cometera reverbera em um sentimento de culpa que nunca o abandonou, culpa por ter sobrevivido.

Ao contrário de Adam Cohen, Stela W. Mayer nunca esteve em um campo de concentração, mas vive um quotidiano de ligação com o passado dos pais. Na carta que a mãe lhe escrevera de Ravensbrück, cuja cópia traz consigo na bolsa, Maria Mayer expressa o desejo de continuar a 
viver para reencontrá-la e pede-lhe que seja alegre, que dance e cante por seus pais. O pedido feito traduz o laço que continuaria a ligar o futuro da filha ao passado trágico dos pais por meio de um obsessivo dever de memória. No entanto, Stela nunca foi alegre verdadeiramente: "a Stela nunca conseguiu realizar o que a sua mãe lhe pediu: nunca foi totalmente alegre". Traz consigo o sentimento de culpa e empatia pelos que se foram sem se dar a permissão de ser alegre, de viver impunemente: "Na verdade, a Stela nem sempre se permitiu as alegrias e os prazeres deste mundo [...] E a razão da Stela ser assim está ligada ao que aconteceu aos seus pais e a ela própria na Alemanha nazista" (Drummond 1984: 29).

Além de se sobrecarregar de trabalho, evita toda forma de prazer e alegria: "Nessa época, a Stela se sobrecarregava de trabalhos, deveres, e evitava as alegrias e prazeres" (Drummond 2003: 44). Inclusive realizando abstinência alimentar algumas vezes por semana: "Stela fazia uma espécie de abstinência em certos dias da semana, cortava os pratos alemães de que tanto gostava e mesmo a cerveja" (ibidem). De fato, a memória dos que morreram não a abandonou e era irrealizável conciliar as duas experiências, prazer e culpa. O sentimento de culpa ao lembrar-se da mãe no campo de concentração a faz recuar, impedindo-a de ser alegre. À indolência dos prazeres, responde com a restituição da memória dos pais e de seu sofrimento:

Eu estava dançando muito feliz e aí...- E aí? perguntei. -Aí eu lembrei da minha mãe no campo de concentração de Ravensbrück - disse Stela. - Eu a vi na minha frente, muito magra e vestida com o uniforme azul e cinza das prisioneiras e com um lenço escondendo a cabeça raspada. (Drummond 1984: 45-46)

Assim, o sentimento de infelicidade pelo destino dos pais é para ela uma forma de fidelidade à memória dos mesmos. Sofrer pelo que acontecera era manter viva a memória daqueles que foram barbaramente assassinados. Tem que remoer o passado, viver a culpa pelo fim trágico dos pais. Ir à Alemanha para recuperar a memória de sua mãe é o principal objetivo de Stela, o que lhe dá sentido à vida: "Stela mudou de ideia e disse que ia guardar os dólares para quando fosse viajar e reconstituir a vida de sua mãe em Ravensbrück "(Drummond 1984: 43). Stela representa a memória da segunda geração, herdeira de um trauma apesar de não o ter vivido diretamente. No entanto, a memória do passado traumático dos pais é transposta para o seu quotidiano, tornando-se tão relevante quanto o próprio passado:

Não, eu não posso esquecer quem eu sou - ela continuou. - Não posso esquecer que a Gestapo matou meu pai num anoitecer em Berlim. Não posso, e eu nunca vou esquecer o que a Gestapo fez com minha mãe, naquele mesmo anoitecer de Berlim. E não vou esquecer o que minha mãe passou no campo de concentração de Ravensbrück [...] Não posso esquecer de mim mesma, sendo criada até os cinco anos dentro de uma caixa d'água em Berlim por Frau Deutschland - ela dizia- Não posso esquecer o que Frau Deutschland e eu passamos quando Berlim estava sendo bombardeada. (idem: 47) 
A memória que deve preservar é, sobretudo, a que lhe foi transmitida pela mãe adotiva ou na carta enviada pela própria mãe. Como toda uma geração herdeira do traumatismo vivido pelos pais, aos quais esse passado chega de maneira muitas vezes sub-reptícia, Stela W. Mayer tem o seu presente preenchido pelas lembranças dos pais. Tais lembranças, como afirma Hirsch no tocante à pós-memória, são mais relevantes que as suas próprias lembranças e acabam ocupando um lugar privilegiado no quotidiano e na memória da segunda geração (Hirsch 2012: 19). De fato, o projeto central de Stela W. Mayer é viajar à Alemanha para reconstituir a vida de sua mãe em Ravensbrück.

Publicado quarenta anos após o desaparecimento da irmã, K. Relato de uma busca surge concomitantemente à abertura de parte dos arquivos secretos da ditadura militar à sociedade civil e à criação da Comissão Nacional da Verdade, comissão instaurada em 2011 para investigar violações aos direitos humanos no Brasil durante o regime militar, embora sem valor jurídico. O tema da autoficção e dos anos de repressão não se esgota nesse primeiro romance e tem continuidade em seus livros publicados depois: Você ainda vai voltar para mim (2014) e Os visitantes (2016). Em entrevista, Bernardo Kucinski compara a escrita de K, já em idade madura, a um processo de catarse pessoal..$^{18}$ Não sabemos até que ponto Bernardo Kucinski se baseou na busca e relatos do próprio pai, mas a tentativa de elucidação do desaparecimento de Ana Rosa Kucinski Silva e de seu marido abre espaço para diversas versões dos fatos, narrativizando o que passou e dando veracidade ao que é, em parte, ficção. Centrada na perspectiva do pai, a narrativa faz ecoar a voz do escritor-irmão, que, como uma sombra lateral tecendo relações entre o presente e diferentes camadas de passado (apud Rothberg 2018: 248), vê de cima o processo que relata, muitos anos depois. Logo, a testemunha é também uma figura central na narrativa.

De fato, em busca do paradeiro da filha, o pai encontra testemunhas que possam levá-lo à filha viva, no início, e, tendo exaurido as suas esperanças, aos restos mortais para dar-lhe dignamente um túmulo. As testemunhas colocadas em cena pelo narrador tanto evocam as tentativas feitas pelo pai para saber a verdade durante o encontro com os diferentes atores que se negam a lhe revelar os fatos como abrem espaço à fala das diferentes testemunhas do desaparecimento de sua irmã e dos demais militantes encarcerados na casa da morte. De maneira polifônica e não hierárquica, o romance dá voz a militares, ao delegado Fleury e à sua amante, à empregada da casa da morte, às colegas de faculdade de Ana Rosa, aos membros da mesma organização política etc.

Por outro lado, a narrativa acaba revelando segredos familiares ao liberar histórias caladas pelos pais sobre o passado na Polônia. Em torno do evento traumático - o desaparecimento e a morte da irmã e da filha - vai se delineando um sentimento de culpa e vergonha, síndrome do sobrevivente. Como nas personagens de Hitler manda lembranças, o sobrevivente sente-se culpado por ter sobrevivido - por que ele ou ela e não o outro ou a outra, Primo Levi e Charlotte Delbo se questionariam. Uma culpa que será remoída, esvaziando a vida de seu sentido e levando-os sempre à "hiper-realidade" do passado, à catástrofe que não puderam impedir, à qual retornam incessantemente (Agamben 2003: 137). Se a experiência é intransferível, já que nenhuma palavra pode restituir o vivido, a "narração impossível "(Felmann 2000: 53), a 
transmissão se faz pelo viés intergeracional - ainda que tudo seja feito para estancá-la de uma geração à outra - e pela possibilidade, dada pela criação literária, de reelaborá-la (Seligmann-Silva 2008: 95). O não reconhecimento do Estado pelos crimes cometidos e o trauma como repetição de uma vivência na memória familiar são as chaves para compreender o processo de culpabilização e a sua transmissão em K. Relato de uma busca.

Primeiramente, o posicionamento omisso do Estado brasileiro vem a corroborar o sentimento de culpa delegado aos familiares. Kucinski a elabora no capítulo "Sobreviventes, uma reflexão" (Kucinski 2016a: 154-156). Relembrando o filme A escolha de Sofia (1982), que narra a história de uma mãe que deve escolher qual dos dois filhos deverá sobreviver, o narrador reflete sobre um sadismo funcional exercido pelo ocupante nazista que transfere à mãe a culpa pela morte do filho. A reflexão feita permite-lhe pensar de que forma, no tocante à ditadura brasileira, o Estado transferiu às famílias das vítimas da ditadura uma certa forma de culpa ou responsabilidade. Culpa que foi intensificada pela anistia imposta, e a indenização paga às famílias, transformando-as em cúmplices da amnésia coletiva e de um processo saldado pela impunidade:

Também os sobreviventes daqui estão sempre a vasculhar o passado em busca daquele momento em que poderiam ter evitado a tragédia e por algum motivo falharam. Milan Kundera chamou de "totalitarismo familiar" o conjunto de mecanismos de culpabilização desvendados por Kafka. Nós poderíamos chamar o nosso de "totalitarismo institucional".

Porque é obvio que o esclarecimento dos sequestros e execuções, de como e quando se deu cada crime, acabaria com a maior parte daquelas áreas sombrias que fazem crer que, se tivéssemos agido diferentemente do que agimos, a tragédia teria sido abortada.

Por isso, também as indenizações às famílias dos desaparecidos - embora mesquinhas - foram outorgadas rapidamente, sem que eles tivessem que demandar, na verdade antecipando-se a uma demanda, para enterrar logo cada caso. Enterrar os casos sem enterrar os mortos, sem abrir espaço para uma investigação. Manobra sutil que tenta fazer de cada família cúmplice involuntária de uma determinada forma de lidar com a história.

O "totalitarismo institucional" exige que a culpa, alimentada pela dúvida e opacidade dos segredos, e reforçada pelo recebimento das indenizações, permaneça dentro de cada sobrevivente como drama pessoal e familiar e não como a tragédia coletiva que foi e continua sendo, meio século depois. (Kucinski 2016a: 156)

Espelhando o desfecho da história de muitas outras famílias, o relato de Kucinski analisa e mostra-nos como o Estado foi exímio em emudecer fatos e transferir a responsabilidade para as vítimas indiretas da ditadura. Como anunciado no primeiro capítulo "As cartas à destinatária inexistente", o não reconhecimento do Estado pelo assassinato da irmã, considerada desaparecida até hoje, infiltra-se de forma absurda no quotidiano da família. $O$ irmão, por razões que ignora, continua a receber em sua casa cartas enviadas por bancos e destinadas à irmã morta. Às cartas, podem ser acrescidos os telefonemas que, quarenta anos mais tarde, continuam 
assegurando que ela ainda estaria viva e no Canadá, uma encenação arquitetada pelo sistema de repressão ainda em ação.

Questões sensíveis sobre a transferência da responsabilidade do Estado à família por meio da lei que anistiava torturadores e os seus mandatários, mas que, no caso da família Kucinski, parece reverberar em histórias passadas e silenciadas e que, para os dois, aparecem como repetição. $O$ ponto de vista do pai-personagem encobre o do filho-autor e remete à transmissão de sentimentos, traumas de pais a filhos, ainda que insconscientemente (Hirsch 2012: 30-31). Entendemos assim que o sentimento de culpa de que nos fala o autor não está ligado apenas à morte da irmã. Em verdade, e de maneira velada, o autor mostra as associações entre o presente da busca e o passado dos pais. De que forma o sentimento de culpa poderia relacionar momentos, em princípio, estanques?

Ainda que Majer Kucisnki tenha morrido em 1976 sem saber onde se encontravam os restos mortais de sua filha, no romance, a morte desta é associada por $\mathrm{K}$ às perdas sofridas durante a Shoá. Para K, ser testemunha indireta do desaparecimento de sua filha remete-o inevitavelmente à sua juventude e à morte de parte de sua família. A Shoá é justaposta ao desaparecimento da filha e o pai é tomado por sentimento de culpa e de punição tardia: "Levava na sacola a sua identificação, a sua memória, a sua prestação de contas; um ciclo de vida se completava, o fim tocando o início e no meio nada, cinquenta anos de nada" (Kucinski 2011: 160). De fato, o sentimento de culpa percorre toda a obra. K. se infringe parte da culpa de não ter estado mais ao lado da filha, de não ter compreendido o caminho que ela vinha trilhando na oposição política, sempre envolvido com o estudo da língua e literatura iídiche. Sente-se culpado por ver a filha ser encarcerada como prisioneira política, assim como ele fora cinquenta anos antes:

Decidiu que escreveria sua obra maior, única forma de romper com tudo o que antes escrevera, de se redimir por ter dado tanta atenção à literatura iídiche, ao ponto de não perceber os sinais do envolvimento de sua filha com a militância política clandestina, alguns tão gritantes que sem dúvida eram pedidos disfarçados de socorro que ele, idiotizado, não percebia. (Kucinski 2016a: 126)

Culpa de quem sobreviveu à perseguição política, ao contrário da irmã, e ao extermínio étnico, ao contrário dos familiares, sentimento reatualizado pela repetição do trauma, a perda da única filha: "Com isso K. concordou, mas retrucou que para ele a tragédia da filha era continuação do Holocausto" ( Kucinski 2016a: 75).

Nesse sentido, a culpa transferida ao pai é também a do próprio irmão. Como um espelho refletido, o mesmo sentimento de não ter agido enquanto era tempo. No caso do irmão, que na Europa publicava um livro denunciando o uso da tortura como política de estado durante o regime militar, ${ }^{19}$ a culpa de não ter percebido o perigo que a própria irmã corria, dado que foi assassinada com requintes de crueldade no Brasil: 
A culpa. Sempre a culpa. A culpa de não ter percebido o medo em certo olhar. De ter agido de uma forma e não de outra. De não ter feito mais. A culpa de ter herdado sozinho os parcos bens do espólio dos pais, de ter ficado com os livros que eram do outro. De ter recebido a miserável indenização do Governo, mesmo sem a ter pedido. No fundo a culpa de ter sobrevivido. (Kucinski 2016a: 155)

Uma história menos eloquente perpassa a narrativa e o drama de um pai em busca de sua filha: o trauma não-dito da própria mãe. No capítulo "Um inventário de memórias", sabemos que a mãe achava a filha feia, por isso, pensa o pai, não terem nenhuma fotografia dela. No entanto, outra razão explicaria essa falta: "A falta de fotografias da mãe explicava-se por sua abulia permanente. A filha nascera em plena guerra, a mãe assombrada pelos rumores de chacinas de sua família na Polônia. Pior, depois, ao crescer com a mãe já derrotada pelas certezas dessas chacinas" (Kucinski 2016a: 111). De fato, a gestação e o nascimento de Ana Rosa Kucinski ocorrem em paralelo à tragédia de que a mãe será testemunha auricular: o extermínio de toda a família pelos nazistas, com exceção de um primo e de uma tia, juntamente com a maioria da comunidade judaica de Wloclawek entre 1939 e $1942 .{ }^{20}$ A razão que permanece implícita e que explica a ausência de fotografias da irmã pequena: a sua primeira infância coincide com os anos de morticídio da família materna.

A culpa da mãe por ter sobrevivido ao extermínio sofrido pelos familiares e conterrâneos é nesse caso exacerbada pelo paradoxo de dar à luz uma criança. A rejeição da filha em seus primeiros anos, a depressão, a abulia e o câncer de que morreria mais tarde são, para o filho narrador, sintomas patentes do mal do sobrevivente, afirmação reiterada em Os visitantes (2016). O olhar da mãe sobre a filha, que considera feia, parece ser a expressão de um desgosto de si e do mundo mais do que uma apreciação estética. O sentimento de culpa, que é também o da filha Ana Rosa, mas que ficará calado, criança rejeitada pela mãe cuja vida surgia em meio a tantas mortes.

O silêncio dos pais sobre o genocídio da família materna não impede a transmissão do trauma e da culpa pela melancolia da mãe. Falar no lugar do outro - da irmã, da mãe, do pai - é, como afirma Agamben, testemunhar uma ausência, a única versão possível, mas incompleta, e que deixará calada a única testemunha ocular da tragédia narrada, a própria irmã. No entanto, ao silêncio da família, o irmão-escritor propõe a fala como testemunho possível dos diferentes traumas, inclusive os seus.

O livro testemunhal, escrito pelo irmão, aparece como mise en abyme daquele confeccionado na história pelo próprio pai:

Desolado pela falta da matzeivá, ocorreu então a K. a ideia de compor um pequeno livrinho em memória da filha e do genro. Uma lápide na forma de livro. Um livro in memoriam. Isso também se fazia de vez em quando na Polônia, embora sem substituir a matzeivá. Comporia um folheto de umas oito ou dez páginas, com fotografias e depoimentos de suas amigas, imprimiria cem cópias e as entregaria de mão em mão para toda a família, os conhecidos e as amigas; mandaria aos parentes em Eretz Israel. (Kucinski 2016a: 77) 
Tendo o rabino negado a matzeivá ${ }^{11}$ à irmã desaparecida - fato que, em Os visitantes, o escritor diz se tratar de pura ficção -, K constrói um livro-lápide de memórias frágeis feito não de cimento mas de fotografias e de depoimentos, para que a dor e o luto, como um kaddish oração fúnebre do rito judaico -, possam ser pranteados. Nessas memórias herdadas, Kucinski também nos propõe um livro-memorial, tecido de palavras, uma mimese que "tenta criar uma sepultura no texto" (apud Seligmann-Silva 2000: 97). Ainda que encarnado pela figura da personagem do pai, a escrita de K. Relato de uma busca revela a investigação levada a cabo pelo filho sobre o passado traumático dos pais. Se o pai tomará conhecimento do assassinato da filha ao término de um longo período de busca, só o filho-irmão-autor saberá o grau de requinte de tortura e barbárie de que foram vítimas a irmã e o cunhado.

Assim, o relato de Kucinski perpassa diferentes camadas memoriais traumáticas vividas por uma família de imigrantes judeus poloneses: da imigração para o Brasil como escapatória ao nazismo ao desaparecimento da filha durante a ditadura militar brasileira. Nesse sentido, Bernardo Kucinski dá voz ao silêncio dos pais sobre o passado da família, à busca empreitada pelo pai, ao silêncio em torno do desaparecimento da irmã e, indiretamente, dá voz aos muitos silêncios deixados em volta dos desaparecidos durante a ditadura militar no Brasil. Na ausência do corpo nunca encontrado da irmã, o irmão-escritor nos lega, a um só tempo, um testemunho e um livro-arquivo revelando a complexa trama do sistema de repressão. Inscrito em uma perspectiva pós-geracional, o testemunho de $\mathrm{K}$, ainda que ficcional, tem o poder de "libertar as (diferentes) cenas traumáticas" (Seligman-Silva), transformando a catarse pessoal em narrativa nacional. Se a missão primeira era a de resgatar a memória e a dignidade da irmã, o romance de Kucinski realiza, de maneira magistral, um trabalho de memória coletivo ao revelar fatos e nuances de um passado nacional anistiado, libertando uma memória impedida (Ricoeur 2000: 575).

\section{Conclusão}

A publicação de Hitler manda lembranças, no final do regime ditatorial, e de K. Relato de uma busca, concomitantemente à criação da Comissão Nacional da Verdade, ocorre em momentos históricos importantes. A emancipação da palavra (escrita) sobre os traumas recalcados confronta-se a um trabalho memorial inacabado. Ao dar a conhecer os fatos que ficaram calados, Roberto Drummond e Bernardo Kucinski dão vida ficcional a histórias e personagens marginalizadas da história, como imigrantes, sobreviventes, vítimas da repressão, tecendo com eles uma complexa trama memorial. Nessa trama, as associações entre períodos históricos diferentes oferecem novos significados aos vestígios do passado.

Assim, a análise dos dois romances nos permitiu refletir sobre o caráter transnacional e intergeracional dos traumatismos históricos. Nos dois casos, a terra de exílio para os imigrantes judeus torna-se o palco para que o drama seja revivido, como rememoração ou repetição. Como foi dito, a ficção apresenta-se como terreno propício para representar essas sobreposições e a sua transmissibilidade. Por meio dela, escritores herdeiros de traumas históricos, ou que com eles estabeleceram uma relação empática e afiliativa, enriquecem com suas narrativas (auto) ficcionais, a memória nacional. 
"Chamada diante do trauma para prestar-lhe serviço" (Seligmann-silva 2008 : 70), a literatura torna-se o espaço memorial no qual o cruzamento de traumas é possível: a Shoá, a repressão política. Graças ao seu efeito de pungência e à sua capacidade de transformar a história individual em experiência estética e ética coletiva, a literatura aparece como campo simbólico relevante para a elaboração de um trabalho de memória que o Estado brasileiro, amparado na Lei da Anistia, resiste em realizar. ${ }^{22}$ Assim, o processo traumático não se encerra com aquele que o vivenciou, mas transforma-se em herança para a segunda geração que, por filiação, empatia ou necessidade de conhecimento do passado, se compromete com um trabalho de memória coletivo.

\section{NOTAS}

* Sandra Assunção é professora Adjunta de Literatura e Cultura Brasileiras no Departamento de estudos lusófonos na Université Paris Nanterre. Doutorado em Letras pela Université Sorbonne Nouvelle-Paris 3 e Universidade de São Paulo. Pesquisadora de literatura brasileira, abordando os temas da margem e periferia; literatura e migração; literatura e memória. Recentemente, co-organizou os dossiês temáticos Narrativas memoriais e pós-memoriais (Revista Letras Raras, 2020), Resistência na literatura brasileira contemporânea (Revista Miscelânea, 2020), Dos espaços do corpo ao corpo no espaço: literatura e cultura (Revista Revell, 2020), Laços de família de Clarice Lispector (Hispanismes, 2021). Publicou, entre outros, os artigos: "L'apprentissage de la fortune", in Michel Riaudel et alii, Hispanismes n 15, Paris, Société des Hispanistes français, 2021; "Em nome dos pais, de Matheus Leitão: um relato (pós) memorial contra o esquecimento", in Gínia Maria Gomes (org.), Narrativas brasileiras contemporâneas: memórias da repressão, Porto Alegre, editora Polifonia, 2020; "L’invention de la nation métisse dans Gabriela, girofle et cannelle de Jorge Amado", in Revue Crisol, n² 21, (2020).

${ }^{1}$ Sobre a literatura brasileira de expressão judaica, ver: Regina Igel, Imigrantes Judeus/Escritores Brasileiros: o componente judaico na literatura brasileira, São Paulo, Perspectiva, 1997 e Márcio Seligmann-Silva, "Literatura da Shoah no Brasil ". Arquivo Maaravi: Revista Digital de Estudos Judaicos da UFMG, vol. 1, nº 1, 2007.

${ }^{2}$ Vide José Pedro Macarini, Crise e política econômica: o Governo Figueiredo (1979-1984) (Texto para Discussão). IE/UNICAMP n. 144, junho 2008.

${ }^{3}$ Dois importantes estudos sobre Hitler manda lembranças e, de modo mais geral, sobre a obra de Roberto Drummond enriqueceram esta análise: Nelson Vieira, "Hitler and Mengele in Brazil: The Testimony of Roberto Drummond" e Maria Lúcia Outeiro Fernandes, Narciso no labirinto de espelhos: perspectivas pós-modernas na ficção de Roberto Drummond (Cf. Bibliografia). 


\section{Cadernos de Literatura Comparada}

Representações do passado traumático em obras de Roberto Drummond e Bernardo Kucinski

${ }^{4}$ Sobrevivente da Shoá e radicado no Brasil em 1955, em Belo Horizonte, Joseph Nichthauser (1928-2010) relata a sua experiência nos campos de concentração na Europa nazista em dois relatos memoriais: Quero viver...memórias de um ex-morto (1972) e A morte de um carrasco (2003).

${ }^{5}$ A este respeito, recomenda-se a obra de referência de Maria Luiza Tucci Carneiro, O anti-semitismo na Era Vargas: fantasmas de uma geração 1930-1945, São Paulo, Perspectiva, 2002.

${ }^{6}$ Por meio da paródia, Roberto Drummond recria o episódio histórico conhecido como plano Cohen. Trata-se de um falso plano judeu-comunista arquitetado pelo capitão integralista Olympio Mourão Filho, simulacro que serviu de subterfúgio a Vargas para decretar três meses de Estado de Guerra em 1937 e, no seguimento, a implantação do Estado Novo. A este respeito, ver: Maria Celina d'Araújo, O Estado Novo, Rio de Janeiro, Jorge Zahar editor, 2000, 17-18.

${ }^{7}$ A respeito do exílio clandestino de Josef Mengele no Brasil, sugere-se a leitura do romance de Olivier Guez, 0 desaparecimento de Josef Mengele (2017). Baseado em extensa bibliografia sobre a vida e os anos de fuga do médico nazista, o relato reconstrói, de forma histórico-romanesca, os anos que o médico passou na América Latina (1949-1979), dois terços dos quais no Brasil.

${ }^{8}$ Pensamos, em particular, na colaboração militar entre a França, os Estados Unidos e governos ditatoriais do Cone Sul. A este respeito, recomenda-se o artigo de Maud Chirio e Mariana Joffily, "Moderniser la répression politique: la stratégie de formation de 'l'homme de renseignement' sous la dictature brésilienne”, Histoire@Politique, n 34, janvier-avril 2018 (www.histoire-politique.fr) e o documentário de Marie-Monique Robin, Les escadrons de la mort. L'école française, Paris, La Découverte, 2004 .

${ }^{9}$ Como consta no relatório da Comissão Nacional da Verdade, publicado em dezembro de 2014, Ana Rosa Kucinski Silva e o marido Wilson Silva foram torturados e assassinados na casa clandestina de tortura em Petrópolis, « A casa da morte ». Ver: Relatório / Comissão Nacional da Verdade. Vol.1 - Recurso eletrônico. -Brasília: CNV, 2014, 344.

${ }^{10}$ Em 2014, O Instituto de Química da Universidade de São Paulo, a pedido da Comissão Nacional da Verdade, anula a decisão de demissão por abandono de cargo de Ana Rosa Kucinski votada em 1975. A Congregação pede formalmente desculpas à família e é inaugurado, no próprio instituto, um monumento em sua homenagem. https://sites.usp.br/comissaodaverdade/ informacoes-disponiveis/caso-ana-rosa-kucinski/

${ }^{11}$ A este respeito, ver a narrativa autobiográfica do autor publicada para o público infanto-juvenil: Bernardo Kucinski, Imigrantes e mascates, São Paulo, Companhia das Letrinhas, 25.

${ }^{12}$ Ibidem.

${ }^{13}$ Em Os visitantes, livro de contos que funciona como díptico do romance, a visitante do primeiro conto ("A velha com o número no braço"), uma sobrevivente de Auschwitz, critica a informação dada pelo escritor no romance K. Relato de uma busca de que os nazistas registravam todos os judeus assassinados, e acrescenta informações sobre os campos de concentração que desdizem, em parte, as informações dadas pelo narrador de K. Relato de uma busca. Como o próprio escritor afirma, Os visitantes dá continuidade a K. Relato de uma busca e foi motivado pela repercussão que este obteve (inclusive pelas controvérsias suscitadas). Bernardo Kucinski, Os visitantes, São Paulo, Companhia das Letras, 2016, 11-16.

14 "Je reviens d'au-delà de la connaissance il faut maintenant désapprendre je vois bien qu'autrement je ne pourrais plus vivre" ["Volto do além do conhecimento É preciso desaprender caso contrário não poderia mais viver"] (tradução livre). Charlotte Delbo, Une connaissance inutile: Auschwitz et après, II, Paris, éditions de Minuit, 1970, 191.

${ }^{15}$ Marianne Hirsch sublinha a intensidade da transmissão de traumas de pais para filhos remetendo-nos ao caso da jornalista Anne Karpf. Em suas memórias, The War after, Karpf relata-nos que a transmissão do traumatismo recalcado pelos pais sobreviventes à filha se dá também por meio de sensações físicas. Karpf tem o braço tomado por eczema e descobre, anos 
depois, que se tratava do mesmo braço em que o número do campo fora tatuado em sua mãe. Os sintomas físicos - mais por transposição do que por identificação - aparecem como repetição do trauma de uma geração à outra. (Hirsch 2012: 121) ${ }^{16}$ Agamben define o superstes, diferentemente do testis, como "aquele que experimentou algo, que vivenciou um acontecimento do início ao fim e pode, portanto, testemunhá-lo". Ao contrário do testis, que desempenha o papel de mediador entre duas partes durante um litígio, o superstes é parcial.

${ }^{17}$ Em Aucun de nous ne reviendra. Auschwitz et après. I, Charlotte Delbo, prisioneira em Auschwitz, testemunha os horrores vividos no campo de concentração. As lembranças anteriores ao campo co-habitam com a vida em suspensão e por um fio neste mesmo espaço. A chegada da primavera traz lembranças de uma humanidade perdida e o apelo sensorial da nova estação, em meio às atrocidades do campo, causam-lhe um choque existencial ao cotejar, na memória, humanidade e desumanização: "Pourquoi ai-je gardé la mémoire ? Pourquoi cette injustice ? [...] Loin au-délà des fils, le printemps voltige, le printemps frissonne, le printemps chante. Dans ma mémoire. Pourquoi ai-je gardé la mémoire ? " (Delbo 1970: 177-178) ["Por que ainda me lembro ? [...] Longe, além da cerca de arame, a primavera volteia, a primavera vibra, a primavera canta. Na minha memória. Por que ainda me lembro ?"] (tradução livre)

18 "A culpa, creio, é o âmago do livro, talvez o motivo que me levou a escrevê-lo e a razão de ter assumido a forma de uma catarse. Não [foram] só as pequenas culpas de K. por não perceber o que vinha acontecendo [com a filha], mas também as minhas. Há dois anos escrevi uma novela que nada tem a ver com o tema, mas logo em seguida escrevi uma série de pequenos contos parcialmente autobiográficos, inspirados na minha família, meu pai, meus tios e primos, meu irmão. Talvez esses contos tenham desencadeado o processo mental e psicológico que me levou ao livro. Isso explicaria porque agora, mas não explica por que não antes. Não antes porque há um momento logo depois do choque do desaparecimento em que se deve seguir vivendo pelos que estão vivos, os filhos principalmente. Passaram-se quarenta anos, os filhos já têm vida própria, eu mesmo me aposentei. Nesse momento se dá o processo de catarse, eu entendo o livro como uma catarse. " ("Bernardo Kucinski e a culpa dos que sobreviveram ", Entrevista ao jornal Deutsche welle, cf. bibliografia)

${ }^{19}$ Bernardo Kucinski e Ítalo Tronca publicam, em 1971, o livro Pau de arara: la violence militaire au Brésil, Paris, 1971, Editions Máspero/Cahiers Libres 215-216. Uma edição em português foi publicada no Brasil, em 2013, pela Fundação Perseu Abramo. ${ }^{20}$ A este respeito, ver: "La mise à mort de la communauté de Wloclawek: Photos inédites ", Centre de Documentation Juive Contemporaine | "Le Monde Juif"1993/1 N 146 | pages 4 à 33. Disponível em: <https://www.cairn.info/revue-le-monde-juif-1993-1-page-4.htm > ( CDJC 1933)

${ }^{21}$ «Lápide colocada no túmulo, em geral um ano após o sepultamento» (Kucinski 2011: 73)

${ }^{22}$ Apesar da criação da Comissão Nacional da Verdade em 2011 e da publicação, em 2014, do relatório sobre crimes cometidos durante a ditadura militar, no entanto sem valor jurídico, o Estado brasileiro foi condenado duas vezes, na última década, pela Corte Interamericana de Direitos humanos por crimes cometidos durante a ditadura: em 2010, de militantes da Guerrilha do Araguaia, majoritariamente exterminada, e em 2018 pelo homicídio do jornalista Vladimir Herzog. Apesar das condenações internacionais, a morosidade em esclarecer as circuntâcias das mortes e em responsabilizar os agentes estatais pelos crimes cometidos encontra respaldo na Lei da anistia que completou, em 2019, quatro décadas. 
Cadernos de Literatura Comparada

Representações do passado traumático em obras de Roberto Drummond e Bernardo Kucinski

\section{Bibliografia}

Agamben, Giorgio (2003), Ce qui reste d'Auschwitz, tradução de Pierre Alferi, Paris, éditions Payot et Rivages.

Coquio, Catherine (2015), Le mal de vérité ou L'utopie de la mémoire, Paris, Armand Colin.

D'Araújo, Maria Celina (2000), O Estado Novo, Rio de Janeiro, Jorge Zahar editor, 2000.

Delbo, Charlotte (1970a), Auschwitz et après. I - Aucun de nous ne reviendra, Paris, les éditions de Minuit.

--, (1970b), Auschwitz et après. II- Une connaissance inutile, Paris, les éditions de Minuit.

Drummond, Roberto (1984), Hitler manda lembranças, Rio de Janeiro, editora Nova Fronteira.

Gagnebin, Jeanne Marie (2018), «Faute, culpabilité et dette», Études Ricœuriennes / Ricœur

Studies, vol 9, n. 2, 137-148.

Guerra, Carlos et alii, (2012), Memórias de uma guerra suja, Rio de Janeiro, Topbooks.

Hirsch, Marianne (2012), The Generation of Postmemory: Writing and Visual Culture After the Holocaust, New York, Columbia University Press.

Kucinski, Bernardo (2013), "Bernardo Kucinski e a culpa dos que sobreviveram", Deutsche Welle Brasil - Cultura <https://www.dw.com/pt-br/bernardo-kucinski-e-a-culpa-dosque-sobreviveram/a-17131513> (último acesso em 20/08/2020).

- - (2016a), K. Relato de uma busca, São Paulo, Companhia das Letras.

-- (2016b), Os visitantes, São Paulo, Companhia das Letras.

- - (2016c), Imigrantes e mascates, São Paulo, Companhia das Letrinhas.

Minczeles, Henri (205), "Yiddish, une civilisation quasi anéantie", Manière de voir: Pages d'histoire occultées, $\mathrm{n}^{\circ} 82$, <https://www.monde-diplomatique.fr/mav/82/> (último acesso em 15/07/2021).

Outeiro Fernandes, Maria Lúcia (2011), Narciso no labirinto de espelhos: perspectivas pósmodernas na ficção de Roberto Drummond, São Paulo, Cultura Acadêmica (Unesp).

Relatório / Comissão Nacional da Verdade, vol.1, recurso eletrônico, Brasília, CNV, 2014, 976 p. < http://cnv.memoriasreveladas.gov.br> (último acesso em 01/05/2021).

Ribeiro, Margarida Calafate/ Ribeiro, António Sousa (2013), "Os netos que Salazar não teve: guerra colonial e memória de segunda geração", Abril - Revista do Núcleo de Estudos de Literatura Portuguesa e Africana da UFF, Botucatu, v. 5, n. 11, 25-36.

Ricœur, Paul (2000), La mémoire, l'histoire, l'oubli, Paris, éditions du Seuil.

Rothberg, Michael (2018), Mémoire multidirectionnelle. Repenser l'Holocauste à l'aune de la décolonisation, tradução de Luba Jurgenson, Paris: Éditions Petra, 2018.

Seligmann-Silva, Márcio (2000), "A história como trauma ", in Catástrofe e representação, São Paulo, editora Escuta, 73-98.

-- (2008), "Narrar o trauma - a questão dos testemunhos de catástrofes históricas", PSIC. CLIN., Rio de Janeiro, vol.20, n.1, $65-82$.

Vieira, Nelson H. (1986), "Hitler and Mengele in Brazil: The Testimony of Roberto Drummond", MFS Modern Fiction Studies, Volume 32, Number 3, Fall 1986, 427-438. 